\begin{tabular}{|c|c|c|}
\hline 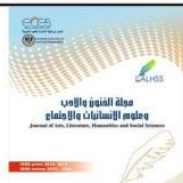 & 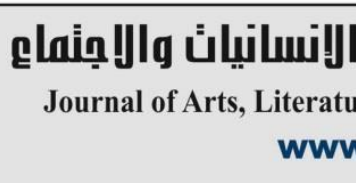 & 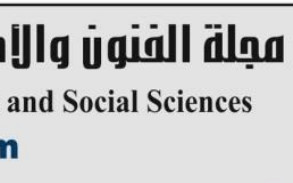 \\
\hline$=$ & Volume (59) October 2020 & العدد (59) اكتوبر 2020 \\
\hline
\end{tabular}

\title{
Security, Political Economic and Social Challenges in Nigeria for the period (2010-2018)
}

Ruqia Mohammed Mahmood

Email: rkia.ra770gg@gmail.com

Prof. Dr. Taha Hameed Hasan Al-Anbaky

Email: taha_aun2004@yahoo.com

College of Political Sciences - University of Mustansiryah - Iraq

\begin{abstract}
Nigeria suffers from economic, social and political challenges, and economic challenges were represented by dependence on one resource (oil), rampant corruption in all the joints of the state, and the high rate of unemployment and poverty. As for the social challenges, they were represented by conflicts between the northern and southern regions (Muslims - Christians) over who would lead the country. Also tribal conflicts over wealth, while political challenges were represented by the absence of political participation and the emergence of terrorist movements, as well as the struggle between political parties over power with one party dominating the joints of the state.
\end{abstract}

Keywords: Security, Political Economic, Social Challenges, Nigeria. 


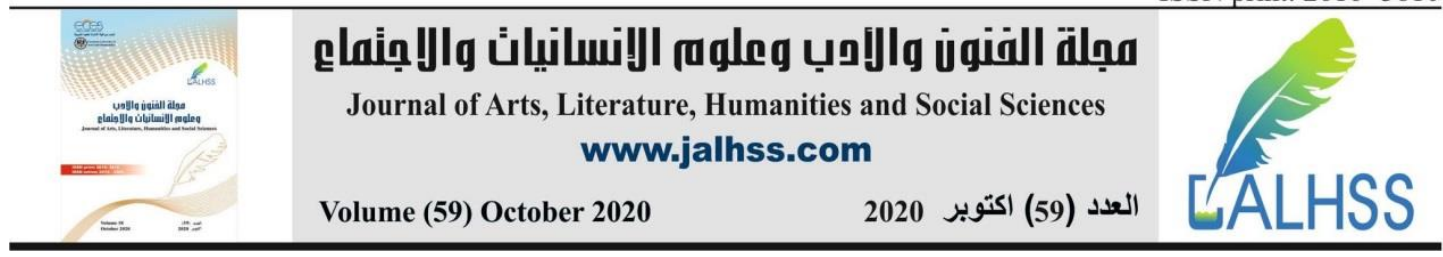

\section{Introduction:}

Nigeria has been facing since independence and until the writing of this paper a set of challenges which cause of the phenomenon of political instability in the country, among these challenges are security, political, economic and social challenges, especially since Nigeria is a community that contain a complex social composition, as it includes more than (250) tribes. Also it has nearly (500) languages and dialects, and among the most prominent tribes at the political level (Haussa-Fulane, Yoruba, Igbo), and this cleared the way for religious, regional and tribal conflicts, in addition to that Nigeria is characterized by oil wealth that made it more vulnerable to the British occupation that contributed In devoting and continuing these challenges, even after Nigeria gained its independence in 1960 and wanted to erase these challenges and achieve stability, but it clashed with the military rule that took control of the country under the pretext of extricating Nigeria from the bad situation and moving it to a better position, and after the coming of the military establishment to The authority worsened the situation, and from here the crises and conflicts increased, and this situation continued from time to time, a military coup until (1999). An interim government was formed to introduce the country to civilian rule and issue a constitution New, and this is what has actually been achieved, with the assume of president (Olusegun Obasanjo), who continued in power until (2007), who is the first civilian president to rule the country, but the civil rule did not achieve anything for Nigeria, especially since all the successive Nigerian governments after 1999 did not It is able to fully perform its duties, although it wanted to achieve progress and prosperity for the country by issuing some reforms, the partisan interests and terrorist movements represented by the (Boko Haram) movement formed an obstacle to achieving these reforms, and as a result this affair led the country to the phenomenon of instability

In light of this, we will divide this research into the following topics:

The first topic: the period of President (Goodluck Jonathan) rule for the period (20102015)

The second topic: The period of President Muhammadu Buhari's rule for the period from (2015-2018)

\section{The first topic}

President (Goodluck Jonathan) government for the period (2010-2015)

Vice President (Goodluck Jonathan) assumed the presidency on $(5 / 5 / 2010)$, in order to fill the vacuum caused by the death of the President (Omar Musa Yar'Adua), who did not complete his term, and Nigeria under the rule of President (Goodluck Jonathan) faced many crises and challenges It destabilized it, and yet the President tried to do everything in his power to face these crises and challenges, and this is what we will address in this request:

\section{The first enquiry: the electoral program and election results}

Nigeria entered at that stage in the process of preparing for the presidential and parliamentary elections, and the number of parties at this stage reached (28) political parties registered in Nigeria, of which five main parties are (Democratic People's Party, Nigerian Labor Conference, All Nigerian People's Party, Alliance Party The 


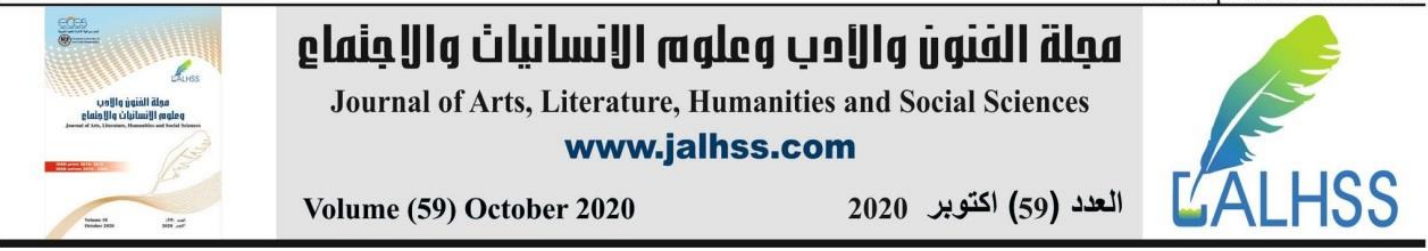

great progression of all progressives, the Party of the Progressive Change Conference), and the (Democratic People's Party) was the one who dominated the government in the country, and the rest of the parties took the position of the opposition $^{1}$.

All these parties have a dialogue mechanism called (consultations between parties), and they formed teams before the elections, which were divided between an observer team and an evaluation team, with the aim of providing the Independent National Elections Commission with information that defines the rules of conduct of the parties and the guidelines covering the election campaign, and on this basis the aforementioned committee completed preparations for elections ${ }^{2}$

Meanwhile, the interim president (Goodluck Jonathan) ran for nomination in the (2011) presidential elections, representing the (People's Democratic Party). The democratic people), and the election program of the interim president (Goodluck Jonathan) included the promise to achieve reforms through which he wanted to improve the economic, social and political situation, and he emphasized the fight against the (Bukhouram) movement, and the interest in the Niger Delta region, as it is considered the region rich in minerals and oil. The oil industry and reliance on multinational companies instead of relying on local companies. Also promised to pay great attention to the electricity sector because it is the vital artery for the country's economy in general and the industrial and agricultural sectors in particular. He also promised to reform the administration due to its importance in building the state and achieving stability and development ${ }^{3}$.

Those presidential elections took place on (1/13/2011), and the candidate (Goodluck Jonathan) won the presidency after obtaining (58.89\%) (see Table No. 20), noting that the number of candidates running for the presidency in In those elections there were (1) candidates. ${ }^{4}$

Table No. (1) shows the results of the 2011 presidential elections

\begin{tabular}{|c|c|c|c|}
\hline Ser. & Candidate & Political Party & Percentage \\
\hline 1 & Goodluck Jonathan & People Democratic Party & 58,89 \\
\hline 2 & Muhammad Buhari's & Graduation Change Conference Party & 31,98 \\
\hline 3 & Nohouribadu & Nigerian Labor Conference Party & 5,41 \\
\hline 4 & Ibrahem Sheckaro & All Nigerian People Party & 2,40 \\
\hline
\end{tabular}

The table was prepared by the researcher depending on the following sources:

Atanda Abdulwaheed Isiaq, Oluwashina Moruf Adebiyi and Adebola Rafiu Bakare: Ethnicity and Election Outcomes in Nigeria - Interrogating the 2015 Presidential Election -, Journal of

${ }^{1}$ Report of the Commonwealth Observer Group, Nigeria Presidential and National Assembly Elections 28 March 2015, UK, 2015 , p.5.

${ }^{2}$ Ibid.p.12.

${ }^{3}$ Jideofor Adibe: The 2015 Presidential Elections in Nigeria - The Issues and Challenges -, Journal of African Foreign Affair, The Brookings Institution, USA, Vol.2 , No.1, 2015, p.3-5.

${ }^{4}$ Ibid., p.3-5. 


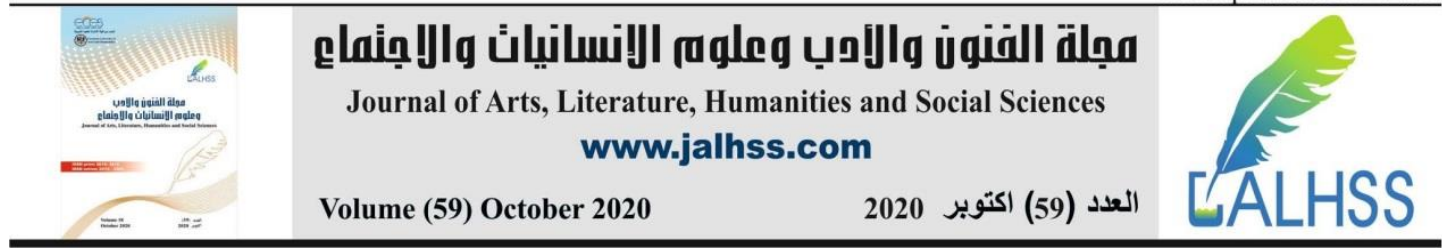

African Elections, Electoral Institute for Sustainable Democracy in Africa, Southern Africa, Vol.17, No. 1, 2018, p. 124-125.Also:

Lansana Gberie: The 2011 Elections in Nigeria - a new dawn -, South Africa, Institute for Security Studies, 2011, p. 16.

From this table, we see that the candidate (Goodluck Jonathan) won the presidency because he obtained the majority of the votes, and thus became the president of the country, knowing that the turnout in the elections reached (53.7\%).

After Goodluck Jonathan elected as a president, he faced objections from the North, and the wave of protests against him escalated in many regions, due to several reasons, including that President (Goodluck Jonathan) was representing the Christian region, and the presidency of the state was supposed to rotate between the north and the south, and accordingly, the presidency of the northerners should be at this stage, because the death of the former president (Omar Musa Yar'Adua) was before the completion of his term, which was within the share of the northerners, just as each tribe saw itself as deserve to rule the country. Goodluck Jonathan had deliberate and practical plans to avoid the problems that the country was exposed to, which led to the aggravation of the situation and the lack of control over the unrest that began to expand, which made it the subject of widespread criticism ${ }^{1}$.

Meanwhile, the election of members of the National Assembly was held for two chambers, as elections for the Senate took place on (4/9/2011), and elections for the House of Representatives took place on (4/26/2011), and a number of political parties participated in them, but it happened in them The People's Democratic Party (PDP) won (205) seats in the Senate, and won (71) seats in the House of Representatives, the highest percentage compared to what other parties got together (see Table 2$)^{2}$.

Table No. (2) shows the results of the (2011) legislative elections

\begin{tabular}{|c|c|c|c|}
\hline Ser.No. & Party & National Assembly & $\begin{array}{c}\text { No. of } \\
\text { Seats }\end{array}$ \\
\hline 1 & Democratic People's Party & Senate & 71 \\
& & House of Representative & 205 \\
\hline 2 & Nigerian Labor Conference Party & Senate & 18 \\
& & House of Representative & 69 \\
\hline 3 & All Nigerian People Party & Senate & 7 \\
& Graduation Change Congress & House of Representative & 36 \\
\hline 4 & & Senate & 7 \\
& & House of Representative & 28 \\
\hline
\end{tabular}

${ }^{1}$ Looking at Amir Saeed: Nigeria - The Map and the Compass - Afrikaans Reading Magazine, Islamic Forum, London, Issue 5, 2010, p.75

${ }^{2}$ Lauren Ploch: Report on Nigeria's 2015 General Elections 28 March and 11 April 2015, The Nigeria Civil Society Situation Room, Policy and Legal Advocacy Center, Nigeria, 2015, p.13.

See also: General Elections in Nigeria 2011, Al Jazeera, on the website: https://www.aljazeera.net/encyclopedia/events/2011/8/11/ 


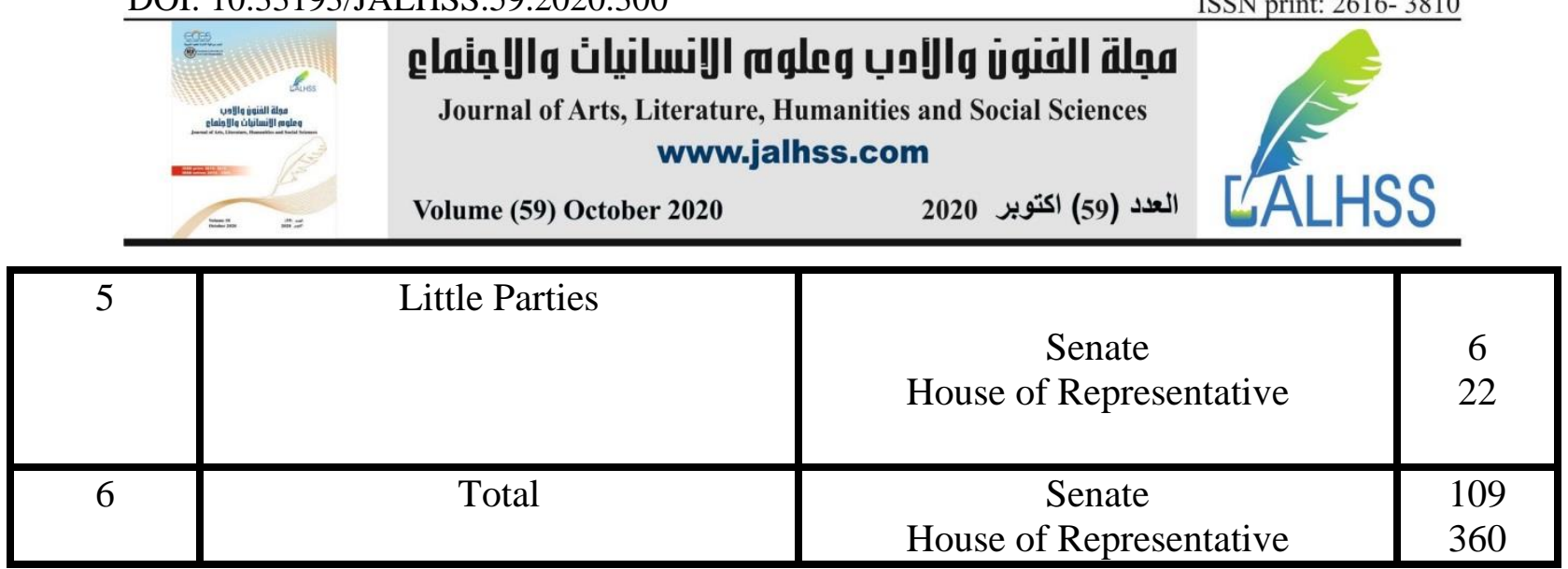

Lauren Ploch: Report on Nigeria's 2015 General Elections 28 March and 11 April 2015, The Nigeria Civil Society Situation Room, Policy and Legal Advocacy Center, Nigeria, 2015, p.13.Also:

Lauren Ploch: Nigeria - Elections and Issues for Congress -, Nigeria, Congressional Research Service, 2011, p.7.

It is explained from this table that the (Democratic People's Party) dominates both houses in the National Assembly, thus imposing its control over the executive and legislative institutions together, and this matter was supposed to be invested by the party in general, and by the president in particular, to implement his electoral reform program, But he was unable to meet the escalating and outdated challenges, and accordingly Nigeria continued to revolve in an orbit of deterioration and instability.

Finally, international circles described the presidential and parliamentary elections that were held in Nigeria in (2011) wasseen positive, and some observers went further when they described them as successful democratic elections, and the Nigerian people put great hopes on them to remove crises and challenges they paid a heavy cost for. ${ }^{1}$.

We conclude from this that the elections in (2011) passed through challenges and obstacles, which the (PDP) fought with the other parties represented by the candidate (Goodluck Jonathan) for the presidency, but he won a high percentage despite the objections from the Northerners who sparked a wave of protests Because President (Goodluck Jonathan) represents the Christian region, as some regions felt injustice, inequality and their ambition to reach power, besides, President (Goodluck Jonathan) was not prepared to develop solutions and plans to avoid the problems that the country was exposed to, as some accusations were directed against him before Political activists said that he was unable to put an end to this unrest, despite that (the Democratic People's Party) won the National Assembly elections with a majority of seats, and from here it can be said that the (People's Democratic Party) controlled the reins of power.

\section{The second enquiry : achievements and challenges}

After (Goodluck Jonathan) assumed the presidency, he undertook several reforms, some of which were administrative and some economic, as he replaced some ministers with new ministers and kept others, especially those who had proven their loyalty to him, and they were - according to his belief - that they were more loyal to

${ }^{1}$ Falade : Political Participation in Nigerian Democracy - A Study of Some Selected Local Government Areas in Ondo State, Nigeria -, Global Journal of Human - Social Science, Global Journals Inc., USA, Vol.14 , No.8 , 2014, p.17. 


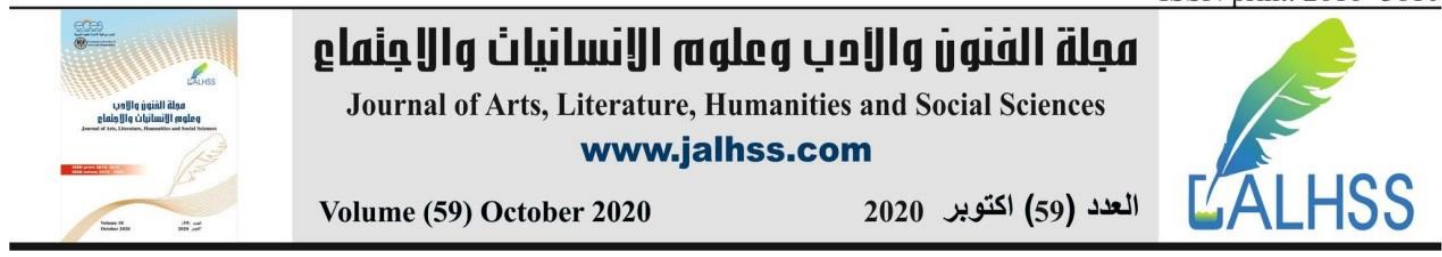

him and the state together, and by what He was the first president from the oil-rich (Niger Delta), and he sought to reassure the people of this region through his development programs there, and showed interest in the oil industry, in order to eliminate unemployment and create new job opportunities in the country, and he also issued an amnesty to the convicts from the region It belongs to it, in order to gain their support and support ${ }^{1}$.

In his first speech, he promised the people that his government would be a reformist government in several areas, including: working to develop the economy, create jobs and achieve comprehensive well-being for all Nigerians. He allocated financial grants to Nigerian students, and expressed his intention to improve the electricity sector, but the president was unable to implement his promises regarding electric power generation, so he asked the people to wait four years to solve the electricity dilemma, but after several changes in this sector the situation improved and there was an increase In the production of electrical energy, especially after spending large sums of billions on this sector, and then the inclusion of this sector with privatization, but the problem in this area was not fair distribution, because the concerned authorities could not provide all regions with the same percentage, due to the scarcity of fuel Which operate the generators, which in turn hindered the development movement ${ }^{2}$.

In his attempt to develop the economy, through improving oil production, he focused on relying on multinational oil companies, because he believed that these companies were more able to build refineries and develop, especially after the delay or failure of local companies in this context, because they were benefiting from importing Some oil derivatives are to achieve their own interests. The President has tried to combat corruption in this sector, criticizing past governments for failing to fight corruption ${ }^{3}$.

$\mathrm{He}$ also stated more than once that poverty threatens life, as there are millions of Nigerians suffering from poverty despite the tremendous wealth that the country possesses, and he was urging ministers to pay attention to health and housing programs

Education is to enhance a sense of national unity, thus overcoming the existing ethnic and religious divisions that colonialism consecrated ${ }^{4}$.

${ }^{1}$ Muddassir Ahmad Gado and Sanusi Abdulwasiu : Challenges Militating against Reform Policy , Economic Growth and Development in Nigeria - Reflections on The Transformation Agenda of Good luck Jonathan's Administration-,Saudi Journal of Humanities and Social Sciences, Scholars Middle East Publishers, United Arab Emirates, Vol.2, No.8 , 2017, p.693.

${ }^{2}$ Oladayo Nathaniel Awojobi : Cultivating Policy for Development in Nigeria - An Appraisal of President Good luck Jonathan's Transformation Agenda (2011-2014),International Research Journal of Humanities ,Engineering and Pharmaceutical Sciences , Association for Innovation , India , Vol.1,No.9,2015 , p.6.

${ }^{3}$ Blessing Thom Otuya : President Goodluk Jonathan's Transformation Agenda and Nigeria's Foreign Policy , Journal Social Science Review , a not-for-pro it organization, USA, Vol.1, No.1, 2015, p.33.

${ }^{4}$ Ibid., p.33-34. 


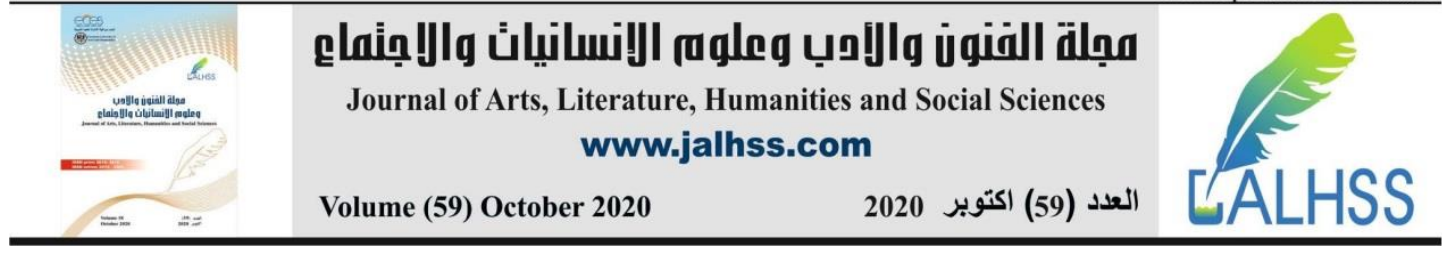

In the field of security, President (Goodluck Jonathan) made great efforts to confront the (Bukhoram) movement and limit its activities, and he was actually able to achieve some victories over it in different regions, but he was not able to eliminate it, especially after this movement changed its approach and carried out More brutal operations such as bombings in crowded places, religious centers and schools, and contributed to the displacement of a large number of citizens from their areas of residence, as it tried to influence public opinion by inciting them against the president as he represents only Christians, yet the president sought to gain the support of neighboring African countries against the movement He sent an important message to those countries, assuring them that the threat of this movement is not limited to Nigeria, but rather will threaten all of them. Therefore, he asked them to cooperate and provide assistance to Nigeria to eliminate this movement before its activities expanded regionally, and in the end this movement hindered the government's efforts to implement Its projects, through the persistence of security risks on the one hand, and the commission of huge funds to the government that affected the state budget ${ }^{1}$. Among the dangers and challenges that president (Goodluck Jonathan) has been exposed to is the increase in tribal, regional and ethnic conflict, especially after it has been increasingly fueled by political parties to achieve their goals. Moreover, those close to the president from the military leaders did not have the sincere intention of their loyalty to the country, rather it was their loyalty. For the region and the tribe, just as the president was not successful in distributing the higher positions in the state, in order to satisfy certain parties at the expense of others ${ }^{2}$. As for the biggest challenge the president faced was the party to which he belonged, as his party aspired to achieve hegemony over power and employ the media To exploit the capabilities of the state in his favor ${ }^{3}$.

The president also failed to improve the living conditions of the Nigerian people ${ }^{4}$, and the most dangerous thing is that the percentage of organized crime has increased in the country, and corruption has spread in state institutions and departments under

${ }^{1}$ Daniel Egiegba Agiboa : The Evolution of Democratic Politics and Current Security Challenges in Nigeria - Retrospect and Prospecy -, Journal Democracy and Security , Taylor and Francis , 2013 , p.14 \& Love Arugu and Comrade John Kalama Mnim : Leadership and The Challenges in Nigeria - An Assessment of President Good luck Ebele Jonathan Administrative Style -, International Journal in Advanced Research in Social Engineering and Development Strategies, Science Publishing Corporation , United Arab Emirates , Vol.2, No.1, 2014 ,p.1.

${ }^{2}$ Kia Bariledum and Others : Foreign Democratic Assistance To Nigeria (1999-2015) - The Nexus Between Strategy and Election Result -, Global Journal of Political Science and Administration, European Center for Research Training and Development, UK, Vol.4, No.4, 2016, p.8.

${ }^{3}$ Alexander Omotayo Bandipo: The role of The New Media in The Electioneering Process of Developing Nations - A Case Study of Nigeria 2015 - , Master Thesis (Not Published), Faculty of Arts , University of Malta, Malta , 2016, p.94.

${ }^{4}$ Remi Chukwudi Okeke : The Jonathan administration in Nigeria - A Postmortem Study and lessons for dictators in Africa -, World Scientific News, Darwin, Poland, Vol.70, No.2 , 2017 , p. 286. 


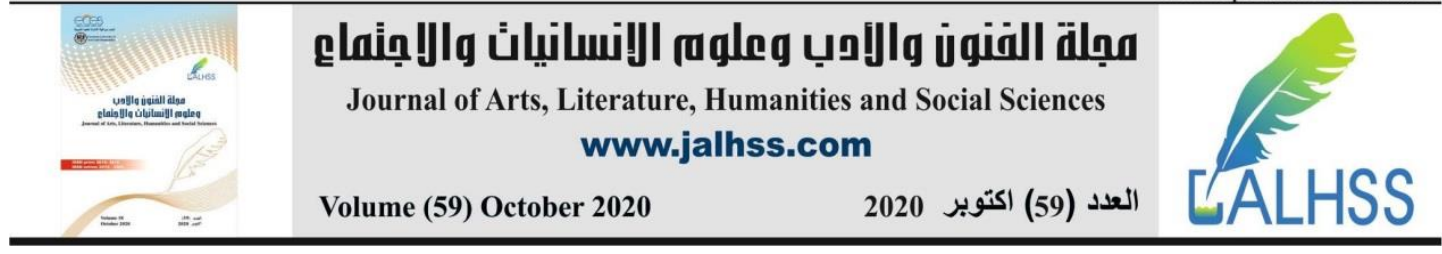

them in light of the lack of accountability and the lack of law enforcement. The abuse of power and the awarding of contracts to those close to officials to implement some investment projects, which constituted an obstacle to the development of public and private institutions, all of which deepened the state of congestion and popular rejection of political reality. Credibility ${ }^{1}$.

From the foregoing, it seems clear that President (Goodluck Jonathan) had made efforts to carry out reforms, including administrative and economic ones, and he promised to carry out economic development, create jobs and achieve comprehensive welfare for all Nigerians, as well as claim to improve the electricity sector and develop the economy by improving oil production. The president tried to eliminate corruption and poverty that threaten the lives of millions of Nigerians, and made great efforts to confront and limit the (Boko Haram) movement, but he faced a number of challenges, including tribal, regional and ethnic conflict, in addition to the biggest challenge the president faced was the party he belongs to. This party aspired to achieve hegemony over power to exploit the state's capabilities in its favor, and during the period of its rule the percentage of organized crimes increased and corruption in state institutions was rampant, and this deepened the state of tension and popular rejection of political reality, which made the government lose its legitimacy.

He aspires to achieve hegemony over power to exploit the state's capabilities in his favor, and during his rule the percentage of organized crimes increased and corruption rampaged in state institutions, and this deepened the state of congestion and popular rejection of political reality, which made the government lose its legitimacy.

\section{The second Section}

The period of President Muhammad Buhari's rule for the period from (2015-2018) President Mohammad Buhari's presidency in his first term was marked by some achievements, but he faced a number of challenges that prevented the achievement of all that he aspired to, and this is what we will be exposed to after learning about his electoral program and the election results.

${ }^{1}$ Sami El-Sayed Ahmed: Political Issues in Africa - The Second African Strategic Report (2014-2015) -, Center for African Research and Studies, International Africa University, Cairo, 2016, p.20. And also:

Okechukwu Eme and Tony Onyishi: The Presidency and Cost of Governance in Nigeria - A Case of Jonathan's Administration -, Arabian Journal of Business and Management Review, American University of Kuwait and Zainab Arabian Research Society for Multidisciplinary issues, United Arab Emirate, Vol. 3 , No. 2, 2013, p. 6.

*The Nigerian All Progressive Congress Party: It is the party that was established in (2013) after the merging of several opposition parties, namely (All Nigerian People's Party, Progressive Change Conference, Nigerian Labor Conference and Grand Alliance Party for All Progressives) in its organizational formation, which was confronted by the (Democratic People's Party) For the first time, by winning the elections in (2015). For more, see:

European Union Election Observation Mission, Final Report on the National Assembly, Presidential, Gubernatorial and State Houses of Assembly Elections, Nigeria, 2003, p. 9-10. 


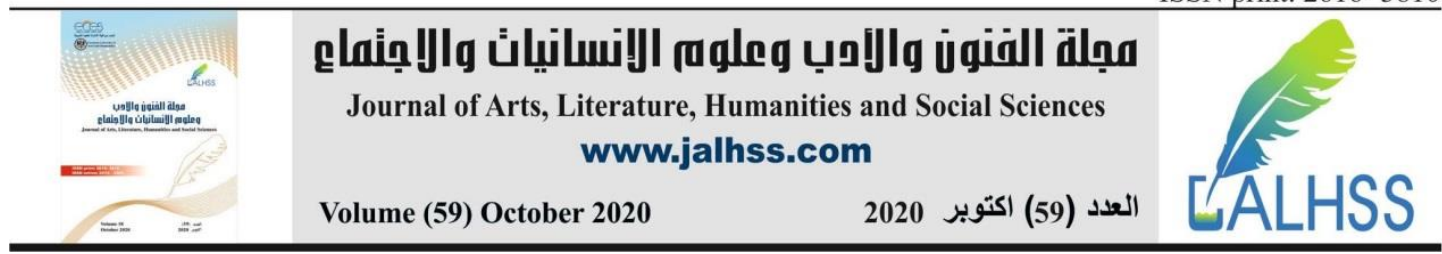

The first enquiry: the electoral program and the election results for the year (2015):

On March 28, 2015, presidential and legislative elections took place simultaneously in Nigeria, and the outgoing President (Goodluck Jonathan), who had the desire for a second term, competed with the candidate (Muhammad Buhari) who nominated him (Congress Party) All Nigerian progressives) *, also won the support of opposition parties ${ }^{1}$.

At a time when President (Goodluck Jonathan) did not have a clear program that could convince the voter to it, the candidate (Muhammad Buhari) adopted an electoral program full of promises, including his intention to implement the social welfare program, and to lift immunity in the event of violations of positions for public employees, and to disclose the assets of officials. And holding the corrupt accountable relentlessly, as he promised to improve the economy to make it a diversified economy instead of relying on oil revenues, and stressed the need to consolidate security and stability by eliminating the (Boko Haram) movement.

In the internal level, as for the external level, he stressed the need not to allow external forces to interfere in the affairs of the Nigerian state. He also called in his program to open up to the world by activating relations with regional countries and world countries in all fields ${ }^{2}$.

The candidate (Mohammad Buhari) won the presidential elections by obtaining a percentage of $(53.96 \%)$, the effect of his superiority over his competitors in (21) states, especially the states: (Lagos, Borno, and Kano) out of (36) states. The victory of (Mohammad Buhari) Muslims residing in the north, as they gave their votes to him thinking that he is their savior from what they were suffering from in the time of the former President (Goodluck Jonathan) - according to their belief - that they will obtain their rights and freely practice their religious slogans during the era of (Muhammad Buhari) There was also a feeling among many Nigerian voters that the latter would fulfill his promises and respond to their demands, and thus the term of the (People's Democratic Party) that had been in power for the period (1999-2015) ended, noting that the turnout was very weak compared to the previous elections. The percentage of voters was $(43.65 \%)$, while the number of registered persons was $(67,422,005)$ (see Table No.3)

Table No. (3) shows the results of the presidential elections for the year (2015)

\begin{tabular}{|c|c|c|r|}
\hline Ser.No. & Candidate & Party & Percentage \\
\hline 1 & Muhammad Buhari & $\begin{array}{c}\text { All Progressive Nigerian } \\
\text { Congress }\end{array}$ & 53,96 \\
\hline
\end{tabular}

${ }^{1}$ Alexander Thurston : Background to Nigeria's 2015 Elections, USA, the CSIS Africa Program, 2015 , p.1.

${ }^{2}$ Ibid.,p.2.

${ }^{3}$ Mojeed Adekunle Animashaun : Nigeria 2015 Presidential Election - The Votes, The Fears and The Regime Change, Journal of African Elections , Electoral Institute for Sustainable Democracy in Africa, South Africa, Vol.14, No.2, 2015, p.201. Also: Ladi Hamalai , Samuel Egwu and Shola Omotola : Nigeria's 2015 General Elections Continuity and Change in Electoral Democracy -, Library of Congress , USA, 2017 , p.10. 


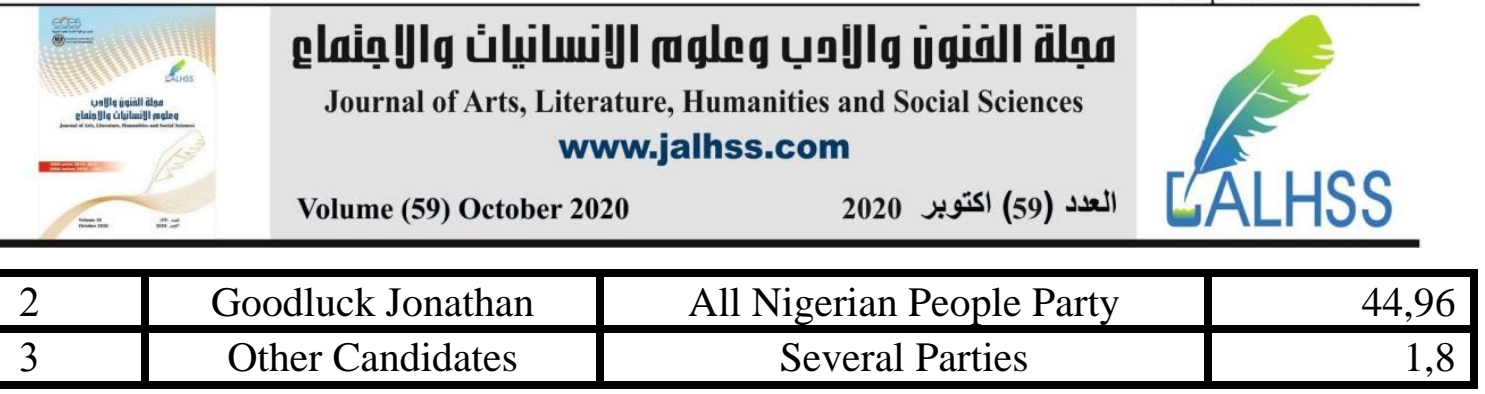

Source :

Nkwachukwu Orji: The 2015 Nigerian General Elections, Journal Africa Spectrum, German Institute of Global and Area Studies, Germany, Vol.50, No. 2, 2015, p.78.

But President (Muhammad Buhari) - like his predecessors - faced a number of accusations ${ }^{1}$, his scientific testimony was questioned, and his daughter was accused of being married to a Christian man, and it was also rumored that he had liver disease ${ }^{2}$.

The opponents of the President (Muhammad Buhari) also questioned the results of the elections, and charged members of the Electoral Commission, and emphasized the existence of electoral violations, including fraud and the participation of voters who had not reached the legal age to vote ${ }^{3}$.

The party that supported the President (Muhammad Buhari) in the legislative elections, namely: The Progressive All-Nigerian Congress Party, won a great victory, winning the majority of seats in the National Assembly in its two chambers: the Senate and the Representatives (see Table No.4) ${ }^{4}$

Table No. (4) shows the results of the (2015) legislative elections

\begin{tabular}{|c|c|c|c|}
\hline Ser.No. & Party & National Assembly & $\begin{array}{c}\text { No. of } \\
\text { Seats }\end{array}$ \\
\hline 1 & All Progressive Nigerian & Senate & 60 \\
& Congress & $\begin{array}{c}\text { House of Representative } \\
212\end{array}$ \\
\hline 2 & Democratic People's Party & $\begin{array}{c}\text { Senate } \\
\text { House of Representative }\end{array}$ & $\begin{array}{c}49 \\
140\end{array}$ \\
\hline 3 & Little Parties & $\begin{array}{c}\text { Senate } \\
\text { House of Representative }\end{array}$ & 8 \\
\hline 4 & Total & Senate & 109 \\
& & House of Representative & 360 \\
\hline
\end{tabular}

The table was prepared by the researcher based on the following sources:

Ladi Hamalai, Samuel Egwu and Shola Omotola: Op. Cit., P. 231. Also:

Nigeria House of Representatives, Inter-Parliamentary Union, 2015, On the link:

http://archive.ipu.org/parline-e/reports/2363_E.htm

It can be said that the (2015) presidential and legislative elections are an important step forward for the sake of democracy in the country despite the large population, and the predominance of the situation of religious, ethnic, tribal, and regional differences, etc. These elections were not without several problems, including

${ }^{1}$ European Union Election Observation Mission, Final Report Federal Republic of Nigeria , 2015, p.35.

${ }^{2}$ See: Hakim Najmuddin: The Nigerian Presidential Elections - Observation and History -, Qiraat Afriqiyah Magazine, The Islamic Forum, London, Issue 25,2015, p. 38.

${ }^{3}$ Hakim Najmuddin: The Nigerian Presidential Elections - Monitoring and History -, a previously mentioned source, p. 39 .

${ }^{4}$ Ladi Hamalai , Samuel Egwu and Shola Omotola : Nigeria's 2015 General Elections Continuity and Change in Electoral Democracy -, USA , Library of Congress , 2017, p.231 


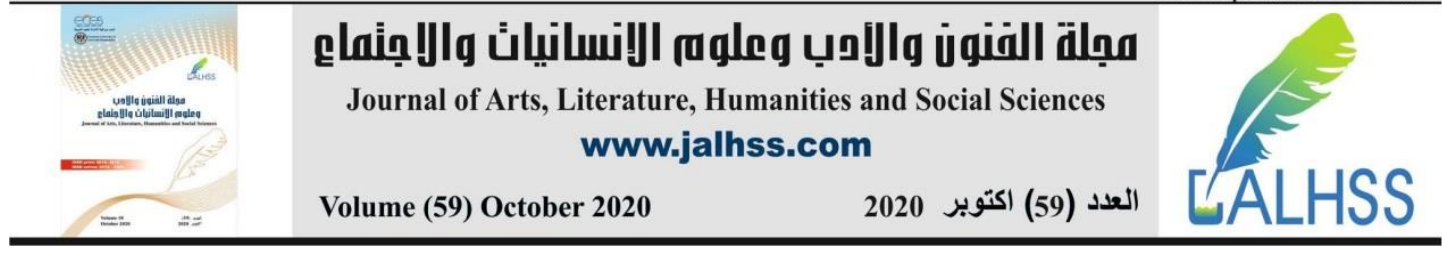

administrative and technical, in addition to the difficult conditions the country is going through, including the escalation of the (Boko Haram) movement and the decrease in oil prices at the time, in addition to the effects of the (Ebola) epidemic, which was a great danger and a negative impact on the country's development.

\section{The second Enquiry : Achievements and Challenges:}

Since President (Muhammad Buhari) assumed his post, he began to implement what he announced in his electoral program, including what he proposed in terms of close solutions to the aspirations of young people in particular and citizens in general ${ }^{1}$.

Thus, he developed a series of plans and projects, as he set plans to eradicate the scourge of corruption that has been exacerbated by the vast resources and wealth that Nigeria possesses in the absence of the authority of law and accountability. , a violation and encroachment on the country's wealth ${ }^{2}$.

On the same track, he tried to consolidate and activate legal frameworks by establishing committees to audit the extractive industries in order to enhance the role of transparency, and he emphasized institutional and financial independence, public prosecution and Proactive by state institutions, prohibiting the use of private aircraft for officials, imposing a travel ban for first-class officials involved in corruption, and scrutinizing the lists of employees and ghost workers from the government wage list $^{3}$. In addition, he set conditions for public employees, which is the disclosure of their liabilities and public behavior before they are appointed, and specialized anticorruption committees that did not exist at that time (the Economic and Financial Crimes Committee, the Practices Committee and the Code of Conduct Office), and these committees practiced auditing officials 'accounts. Senior (political office holders), public and private companies, contractors from the private and public sector, the armed forces and civil servants, and he also tried to dismantle the excess numbers of employees that caused financial mismanagement ${ }^{4}$.

$\mathrm{He}$ also paid great attention to improving the economic situation, developing development plans to raise the standard of living of the individual, and sought to reduce the unemployment rate, as well as decided to work on rationalizing oil revenues in projects that benefit Nigeria, and the president put his hand on oil revenues and their exploitation in the field of factories and technology, as well as the president has restructured the military institution and made it subordinate to the state and not to the parties. He also paid great attention to the education and health sectors,

${ }^{1}$ European Union Election Observation Mission , Final Report Federal Republic of Nigeria , 2015, p.35.

${ }^{2}$ Abdulhamid Ozohu Suleiman :Democracy, good governance and development in Nigeria , Journal of Public Administration and Policy Research , University of Abuja , Nigeria, Vol.8, No.7, 2016, p.81-82.

${ }^{3}$ Macaulay Akpan and Michael Eyo : Anti - Corruption War Under President Muhammadu Buhari in Nigeria - The Arsenal ,Casualties, Victories and Corruption Perception Appraisal -, Global Journal of Politics and Law Research, European Center for Research Training and Development, UK, Vol.6, No.3, 2018 , p.37.

${ }^{4}$ Macaulay Akpan and Michael Eyo : Op. Cit., p.37. 


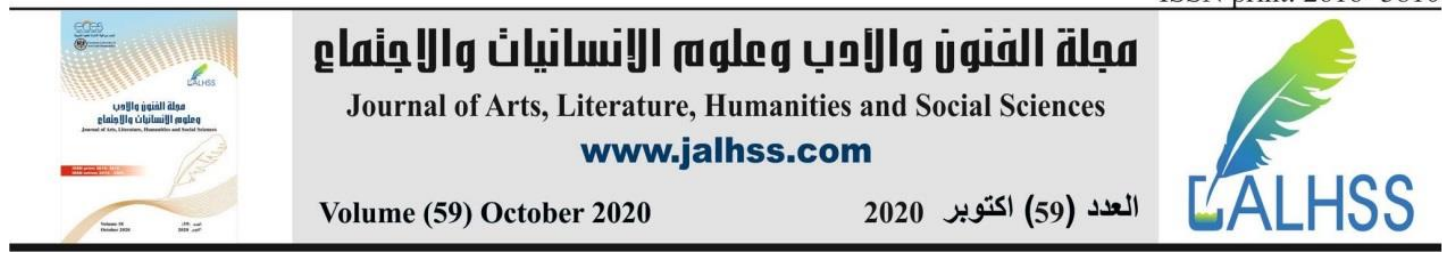

as he believed that these two sectors were the main pillars of building an educated and healthy society capable of facing the challenges facing the country ${ }^{1}$.

President Muhammad Buhari made great efforts by intensifying contacts with foreign countries and coordinating with them to recover the stolen money, and his attendance at international conferences and gatherings invested to achieve this goal, and some countries agreed to his request, including the United States of America, Switzerland and Britain, Switzerland declared that it About (321) million dollars will be recovered from the money that the late former president (Sani Abacha) smuggled out, provided that these funds are used in the development and development of the country. The United Arab Emirates also responded to the same request and strengthened it with bilateral agreements to return the stolen wealth, as these countries recommended Nigeria That she should be concerned with mutual legal assistance in criminal and commercial matters, and furthermore, he was instructed attention to national security to protect the country from external interference, in addition to that he worked to encourage interest in information.

President (Mohammad Buhari) established an electronic unit in the Ministry of Finance to help set guidelines and standards for measuring government spending, so the work of the electronic unit compared the expenditures of the private sector with the government sector ${ }^{2}$.

President Mohammad Buhari was able to implement measures that would improve the capacity of the country's security services, enhance the morale of security men, strengthen the security base and coordinate between the central and state police, and in addition to that, the president was able to contain the security crisis and fight terrorist groups, and this was achieved by resolving the crisis. The abduction of girls, as (103) girls were rescued in (2017), who were kidnapped from (Chibok) school, and (104) other girls were rescued in (2018), who were kidnapped from (Dabashi) school ${ }^{3}$. He also showed interest in the special care of the armed forces and all security personnel and their families Including insurance for their lives, and a promise to reward those who perform heroics and show courage and those who fall on the battlefields in defense of their homeland, and compensate their families in honor of them for the sacrifices they made to the country, and sought to strengthen relations with the rulers of states affected by the rebellion, as well as with neighboring and Western countries In order for coordination with them to bear fruit in order to put an end to armed movements and to curb oil theft and piracy ${ }^{4}$

President Mohammad Buhari was interested in developing security capabilities in terms of logistical support and increasing the number of forces in charge of counterterrorism operations in the northern region, as it jumped from (20) thousand soldiers in (2014) to (50) thousand soldiers in (2017), and sought to Granting the forces

\footnotetext{
${ }^{1}$ Abdulhamid Ozohu Suleiman : Op. Cit. , p.81-82

${ }^{2}$ Macaulay Akpan and Michael Eyo : Op. Cit., p.38.

${ }^{3}$ Freedom Onoha and Samuel Oywole: Boko Haram - The dynamics of the rise and fall of a violent group in Nigeria - Al-Jazeera, p. 5, available on the website.

https://studies.aljazeera.net/en/reports/2018/4/25

${ }^{4}$ Report of the Commonwealth Observer Group , Op. Cit. , p.10-11
} 


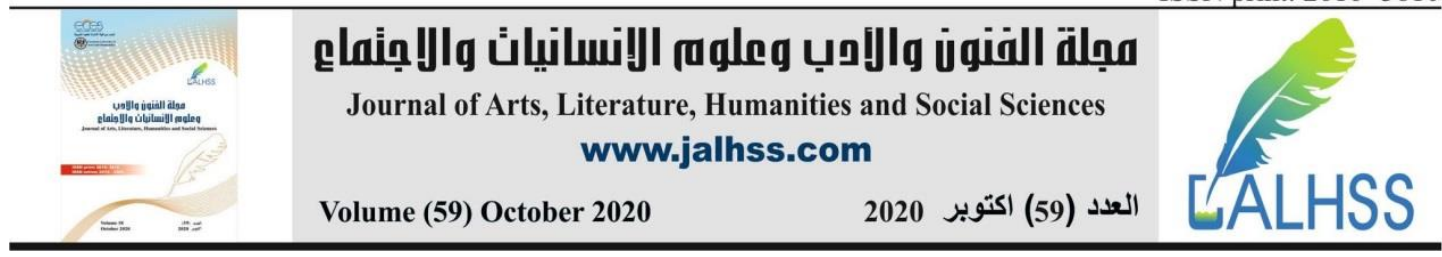

additional salaries to improve their living conditions, and in order to attract some elements of the (Boko Haram) movement, he issued a partial pardon for the members of this movement and their return under the authority of the government and the country's system. His efforts towards this war, due to the agreement of some countries to provide financial aid, training and weapons ${ }^{1}$.

President Mohammad Buhari also proposed a comprehensive economic development program, relying on all sectors in order to create job opportunities for employment, vocational training, skills development and facilitate access to soft loans

The credit facilities, and the government also equipped support programs for the youth, was aimed at developing their capabilities and supporting their business plans, and this step was one of the government's initiatives that were in line with its promises, and this is what President (Mohammad Buhari) achieved after he resorted to the International Monetary Fund as a treatment solution. For the economic problem that Nigeria suffers from, however, President (Mohammad Buhari) rejected the condition according to which Nigeria should commit to devaluing the currency, because it was among the challenges facing the government ${ }^{2}$.

And he sought to find job opportunities through the public works program, especially the construction of a national railway, as well as interest in other roads and ports, and these projects were the first by the government of (Muhammad Buhari), as these projects included providing (3) million job opportunities in all sectors. He also strengthened his relationship with the states to transform northern Nigeria into a source of food production to neighboring countries, and he adopted a new system, which is granting interest-free loans to develop and improve the work of agriculture, and he established a federal agency tasked with following up the implementation of projects for public works, with a focus on Nigerian workers. He also used sports as a source to create job opportunities for the unemployed by equipping athletes and exporting them to international clubs, and he was interested in information technology and professional communication through outsourcing, which in turn contributed to creating new jobs ${ }^{3}$.

President (Muhammad Buhari) imposed on foreign contractors to implement plans and projects that contribute to developing local capabilities (technology and the like), and he sought to develop new oil refineries to reduce import costs and use energy to create jobs and provide additional funds for the country. The unemployed people with extensive knowledge of information, communication and technology, as it signed a memorandum of understanding with the (Chinese Huawei) company in (2015) to train (2000) Nigerians in the field of information and communication technology, and

${ }^{1}$ Ibid. ,p. 12.

${ }^{2}$ Taiwo J.N and Agwu M.E : Problems and Prospects of Poverty Alleviation Programmes in Nigeria , International Journal of Business and Management Review, European Center for Research Training and Development, UK , Vol.4,No.6, 2016 ,p.19.

${ }^{3}$ John Paden : Muhammadu Buhari - The Challenges of Leadership in Nigeria -, Journal of International and Global Studies, Center for African and Asian Studies , Nigeria , 2016, Vol.10, No.1, p.186. 


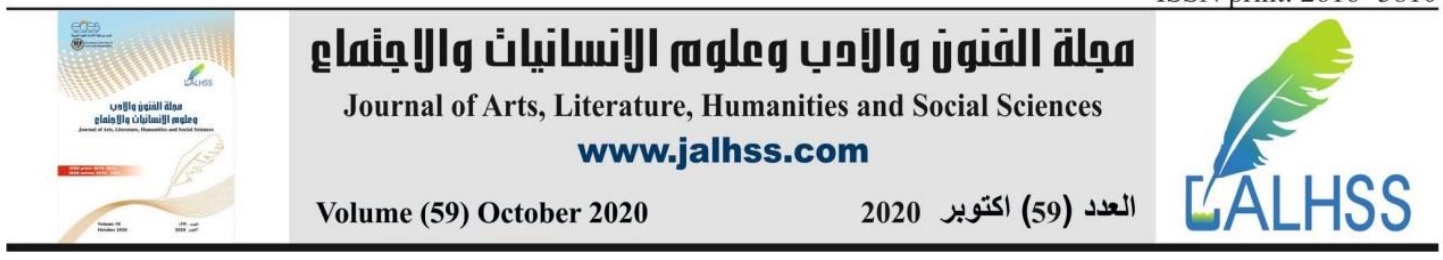

another similar memorandum of understanding with the company (Global), but these notes did not Implement ${ }^{1}$.

In his economic policies, President Mohammad Buhari relied on diversifying the economy instead of relying on the oil sector. He began to develop the agricultural sector by studying the challenges that previous governments had suffered from, and among those challenges was the failure to allocate sufficient arable land to meet the market need and migrate from the countryside to Urbanization, leaving agricultural lands sometimes, lack of access to sustainable credit facilities for farmers, reliance on food imports, inadequate infrastructure and marketing, and all these challenges made the president take a clear approach to developing agriculture, as he followed an agricultural extension approach, and sought to renew and revitalize agricultural research institutions and encourage youth The president and his government were unable to fulfill the promises they had taken upon themselves in this sector, due to the situation Nigeria experienced in terms of internal conflicts, low oil prices, and corruption that was an obstacle to all the programs that he proposed ${ }^{2}$.

In addition, the President tried to exploit the mineral resources that characterize Nigeria, being a second resource to eliminate the financial deficit in the country, and among those minerals (gold, limestone, lead, gem stones, zinc and granite), as previous governments had exploited these wealth in their favor, and thus they went Its imports are to the assets of the corrupt without going to the state treasury and benefiting from it in implementing their development programs ${ }^{3}$.

Thus, President (Mohammad Buhari) was able to employ the entirety of this sector's production and development, to be the main supporter of the Nigerian economy, and established an office specialized in the area of lands rich in minerals, as well as tried to improve the tax law in favor of the investor and expand the mapping in the air in the country, in order to discover places rich in minerals Thus, Nigeria ranked tenth among the African countries that attract investment in (2015), according to the (Fraser Institute) report ${ }^{4}$.

The President also made several promises to address the problem of electric power supplies, which is the main means of building the economy and infrastructure ${ }^{5}$, and has already been able to develop distribution and production networks, until the

${ }^{1}$ Ibid., p.186. Also : Idayat Hassan : Matching Campaign Promises, Public Expectations and Government Actions in The First Year of President Muhammadu Buhar's Government, Nigeria ,Center for Democracy and Development , 2016, p.39.

${ }^{2}$ Mohammed Yamma Abdullahi and Yahuza Lzom Danjuma : Assessment of Value Based Leadership Style of President Muhammadu Buhari (2015-2018), Research Journal of Humanities, Legal Studies and International Development, Center for Promoting Ideas, USA, Vol.3, No.1, 2019, p.46.

${ }^{3}$ Ibid., p.46.

${ }^{4}$ Idayat Hassan , Op. Cit., p.45.

${ }^{5}$ Mohammed Yamma Abdullahi and Yahuza Lzom Danjuma : Op. Cit., p.40. 


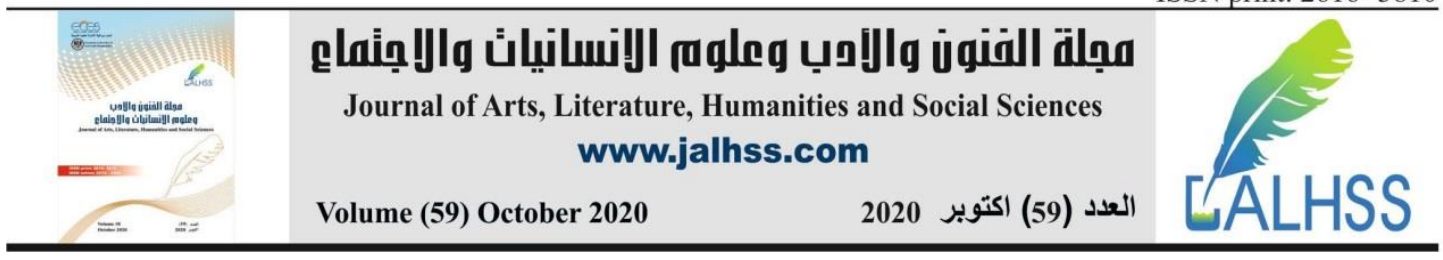

capacity of electric power generation reached (10) thousand megawatts in (2018) after it was (8910) Megawatt years (2011) ${ }^{1}$.

And after the president realized that the production of electric power needs gas supplies, and this was the first challenge in this sector, as well as the lack of water, transportation and lack of maintenance for power stations, all of which were the reason for reducing the electric power, so he decided to conduct a general and urgent review of his plans in the field of the electricity sector He also instructed to encourage investment and initiate the development of infrastructure for electric power, but the latter was subjected to sabotage by armed groups in the Niger Delta, and this made the government reluctance to implement its promises through its inability to put an end to the movements of these groups, which confused the work of investment companies And he left this sector dependent on small companies, and this matter pushed the President (Muhammad Buhari) to search for energy alternatives that would be easier to provide than gas, which was the important artery for the electricity sector, such as (coal, wind, solar and hydropower) ${ }^{2}$.

The oil industry is one of the largest important industries in Nigeria in particular and at the level of Africa in general, and it had the largest share in raising the level of the country's economy, as the oil industry played a major role in protecting Nigeria's economy when the world went through the crisis of low crude oil prices in 2014 through Filling the local market's need for production, as Nigeria did not import any kind of oil derivatives from neighboring countries during the rule of President (Muhammad Buhari), but rather was satisfied with its own production ${ }^{3}$.

The President (Muhammad Buhari) was also concerned with improving and qualifying the transport sector, because this sector did not witness much interest from successive governments, as it provided insignificant funds to implement several necessary steps in the transportation system, as he built highways, modernized the aviation and ports sector and developed the waterway. Internal, as he encouraged nvesting in building the metro inside the city and the bus system, and making all these roads safe after placing them under security control, but this sector did not reach the required level, and the president also paid attention to potable water, sanitation and housing, and promised that he will make all his efforts to solve the dilemmas that plague them These sectors ${ }^{4}$.

${ }^{1}$ Erepamo Osaisai : Country Nuclear Power Profiles 2018 Edition, The Federal Republic of Nigeria , Austria , International Atomic Energy Agency ,2018.p.5.

${ }^{2}$ Idayat Hassan :Op. Cit.,p.48.

${ }^{3}$ Joy Uyo Ata - Agboni and Beluchi Nwanisobi : Economic Recovery Programmes of Buharl's Administration As Developmental Stage Paradigm ,International Journal of Public Administration and Management Research ,Research Center for Management and Social Studies, India, Vol. 5, No.1, 2019 , p.42.

${ }^{4}$ Musa Hyelladzira Wakawa: Causes of Nigeria's Recession - Uneclpsing The Blame on The Previons Administration -, SSRN Papers , 24 Apr 2018 , p.25. On The link :

https://ssrn.com/abstract=3157154 


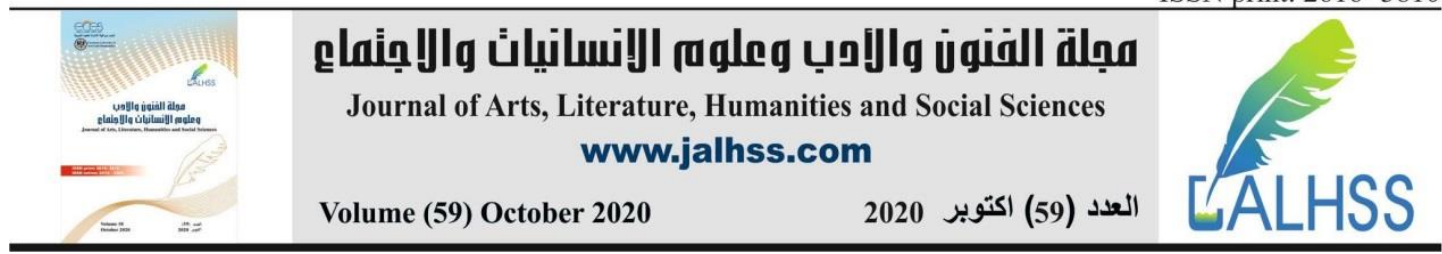

In the last year of his rule, he wanted to change his system of selecting ministers, and also took measures, including reducing personal protections, in order to reduce the doors of exchange, and exempting officials from legal immunity, so that they would be subject to legal accountability in the event of suspicions of corruption, and he also wanted to prove to the people The Nigerian states that these measures are in the interest of the citizen at this stage Nigeria is going through, by extricating it from the economic and security crises ${ }^{1}$.

Despite all the efforts made by President (Mohammad Buhari) aimed at achieving comprehensive development, he faced a number of problems and challenges. At the beginning of his rule, President Mohammad Buhari clashed with the deteriorating economic situation that the country was suffering from, and the unemployment rate was high, and corruption was Rampant, as Nigeria was classified as one of the countries with high corruption, according to Transparency International, Nigeria ranked (136) out of (176) the most corrupt country in the world for the year (2015) (see Table No.5), despite Nigeria's leaders announcing that they have entered a phase The application of democracy and the state of law and institutions, but this did not prevent the spread of the phenomenon of administrative, financial and political corruption due to the concentration of political and party leaders on monopolizing power and wealth on the one hand, and the deterioration of the security and economic conditions on the other hand, and thus Nigeria witnessed the spread of bribery, extortion of money, theft of public resources, fraud and operations Embezzlement, fraud and dishonesty of budgetary accounts ${ }^{2}$.

Table No. (5) shows Nigeria's position in global corruption indicators

\begin{tabular}{|c|c|c|}
\hline Year & Grade & Position \\
\hline 2011 & 22 & 143 \\
\hline 2012 & 27 & 141 \\
\hline 2013 & 25 & 144 \\
\hline 2014 & 27 & 136 \\
\hline 2015 & 26 & 136 \\
\hline 2016 & 28 & 136 \\
\hline 2017 & 27 & 148 \\
\hline 2018 & 27 & 144 \\
\hline
\end{tabular}

The table was prepared by the researcher based on the following sources:

1. Kuwait Transparency Society: Corruption Perceptions Index 2016, Transparency International, 2017, p.10.

2. Transparency International: Corruption Perceptions Index 2018, Germany, 2019, p. 3.

${ }^{1}$ Pallavi Roy : Ant - Corrupton in Nigeria - A political setlements analysis - , UK , University of London , 2017, p.67.

${ }^{2}$ Dickson Monday and Ezirim Gerald : The Political Economy of Recession in Nigeria's Fourth Republic , African Journal of Political Science and International Relations, Academic Journals, Vol.11, No.7, 2017, p.198. 


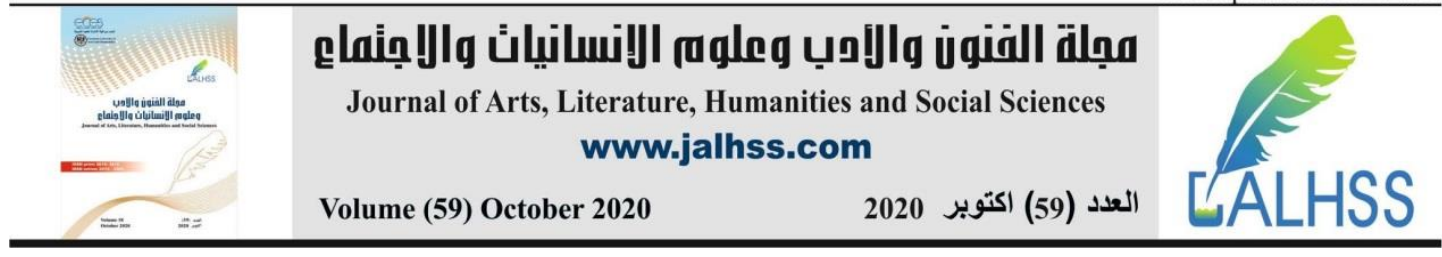

3.Transparency International: Corruption perceptions index, Germany, 2011, 2012, 2013, 2014, 2015, 2017.

Based on the table, we conclude that Nigeria suffers from the phenomenon of political corruption at all political, economic and social levels, which leads to political instability in the country.

Corruption in Nigeria has been linked to successive governments through the chaos that state institutions were suffering from, as well as the interference of military leaders in political and civil life, and the accompanying violations of human rights and public freedoms, and this is what prompted civil society institutions to demand reform and fight corruption, but it did not meet That call will be heard by those who hold power ${ }^{1}$.

Therefore, the phenomenon of corruption worsened with the passage of time, as public positions were used by officials for personal gain, and this was embodied by various means, most notably government contracts and appointments.

Regarding bribery and financial blackmail, in addition to that, Nigeria was suffering from the phenomenon of political and partisan conflicts, as most of the political parties and forces were focusing on clinging to power, and then they were not keen on building the state and achieving development ${ }^{2}$.

Therefore, political parties, movements and forces, some of which have a military character, have focused all their efforts to gain power and seize resources and wealth, exploiting their positions and their influence on Nigerian society, and thus achieving gains through their unofficial funding from the state. On the other hand, she used to raise unrealistic slogans and propose projects that are not applicable but for illicit gain at the expense of public money ${ }^{3}$. Civil State $^{4}$.

A number of political leaders have opened special accounts for them in foreign banks to transfer funds that were acquired by various illegal means, in addition to the control of some officials over Nigerian banks, especially the Central Bank of Nigeria, to benefit from them in investing money and currency to facilitate their financial transactions, including the implementation Contracts and projects they have acquired, regardless of their feasibility or actual completion ${ }^{5}$.

It is interesting to note that most of the governments in Nigeria had been overthrown by military forces and political parties that pushed the slogan of combating the phenomenon of corruption and achieving reform in order to gain popular support, but

${ }^{1}$ IIesanmi Akanmidu Paul : A Historical Perspective of Petroleum on Nigeria's Economic Crisis Since Independence, Global Journal of Human - Social Science, Global Journals Inc., USA, Vol.15, No.2, 2015,p.22.

${ }^{2}$ Adams Oluwadamilola Kemi: Nigeria's Economy Challenges - Causes and Way Forward -, Journal of Economics and Finance , International Organization of Scientific Research , India , Vol.10, No.2, 2019, p.79.

${ }^{3}$ Lauren Ploch Blanchard and Tomas Husted : Nigeria - Current Issues and U.S. Policy -, USA , Congressional Research Service, 2019 , p.2.

${ }^{4}$ Ibid., p.5.

${ }^{5}$ Robert Dode : The Political Economy of Resource Curse and the Niger Delta Crisis in Nigeria - Matters Arising -, European Journal of Sustainable Development, Science and Public Administration University of UYO, Nigeria, Vol.1 , No.2 ,2012, p.53. 


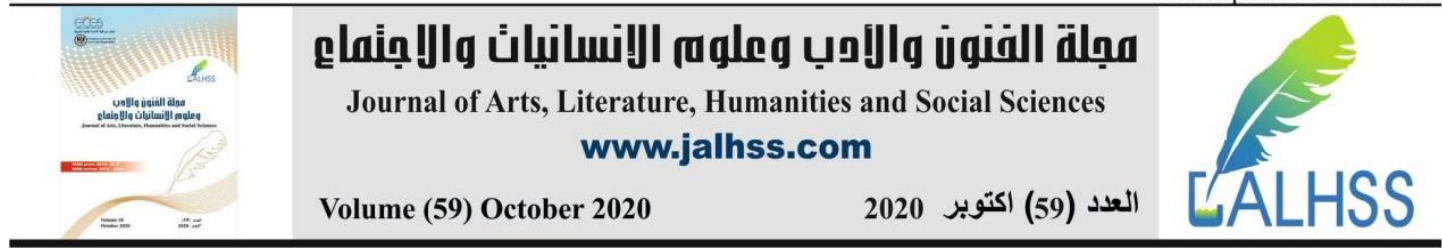

they cannot seize power until the same method of monopolizing power and wealth is repeated, and thus it continued and even worsened the state of deprivation, poverty, unemployment, and the deterioration of the economic and security conditions 1 .

The phenomenon of corruption has left many negative manifestations for Nigeria, including: the exacerbation of external debts, failure to implement the promised projects, and deterioration of the infrastructure in the country. With regard to foreign debts, it recorded nearly (20) billion dollars according to the statistics of $(2018)^{2}$ (see Table No.6), while the gross domestic product for the year $(2018)$ reached $(404,649)$ billion US dollars ${ }^{3}$, and the reason for that is not to invest its money in productive projects or even service projects, and then the inability to repay it with the accumulation of interest on it, as well as failure Development plans and the accompanying misdistribution of oil revenues, in addition to the delay and stopping of many projects for which funds have been allocated within the paragraphs of the annual general budgets of the state, in addition to the presence of other projects that the country did not need but were completed without benefiting from them ${ }^{4}$.

Table No. (6) shows the external public debt owed by Nigeria in US dollars

\begin{tabular}{|c|c|}
\hline Year & Public Debt in Dollar \\
\hline 2007 & 1.14 \\
\hline 2008 & 1.36 \\
\hline 2009 & 1.53 \\
\hline 2010 & 1.79 \\
\hline 2011 & 2.32 \\
\hline 2012 & 2.66 \\
\hline 2013 & 3.59 \\
\hline 2014 & 4.23 \\
\hline 2015 & 5.47 \\
\hline 2016 & 9,01 \\
\hline 2017 & 14.99 \\
\hline 2018 & 20.10 \\
\hline
\end{tabular}

${ }^{1}$ Esekumemu Victor Clark : The Politics of Oil in Nigeria - Transparency and Accountability for Sustainable Development in the Niger Delta -, American International Journal of Contemporary Research, Center for Promoting Ideas, USA, Vol.6 , No.4 , 2016 , p.76.

${ }^{2}$ Cordelia Onyinyechi Omodero and Ogechi Eberechi Alpheaus : The Effect of Foreign Debt on the Economic Growth of Nigeria , Management Dynamics in the Knowledge Economy , Faculty of Management Studies - University of Delhi , India , Vol.7 , No.3, 2019 , p. 292.

${ }^{3}$ Department of Economic and Social Affairs: Handbook of World Statistics, Statistics Division Journal, New York, Issue 42, 2018, p. 252.

${ }^{4}$ Zhenbo Hou and Others : The Oil Price Shock of 2014 , London , Overseas Development Institute, 2014, p.12. 


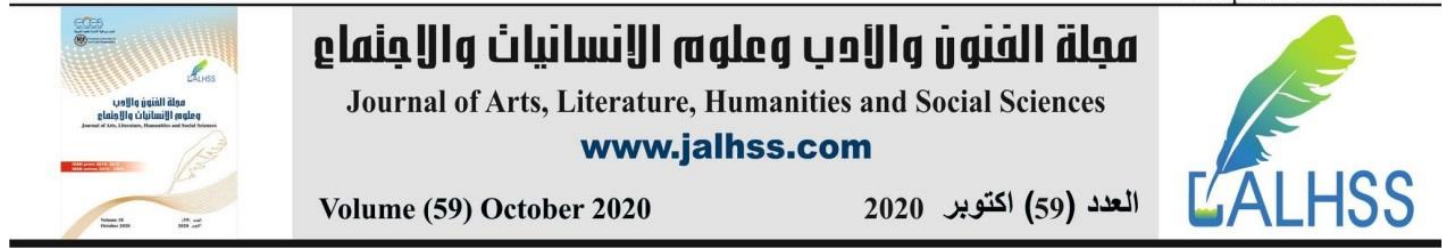

The table was prepared by the researcher depending on the following sources:

Lucky Ujuju and Godday Oboro: The Nigeria Debt Structure and its Effects on Economic, International Journal of Business and Management Review, European Center for Research Training and Development, UK, Vol.5, No. 10, 2017, p.84. Also:

Cordelia Onyinyechi Omodero and Ogechi Eberechi Alpheaus: Op. Cit. , p. 292.

With regard to the development programs in the field of education and public health, they were not the focus of the government's attention to the extent that it reflected positively on the social and economic conditions, for example the neglect of the educational and educational staff until it came to the point of not paying their salaries for 4-6 months, and this is what generated further deterioration, and some schools were forced to leave and closed in some areas, with the accompanying lack of funding for schools and universities, which contributed to the spread of illiteracy, and the infrastructure was ineligible to establish a modern education system, despite some attempts by the government to reform the educational system And educational, but it was not able to improve this system ${ }^{1}$.

The health sector was also suffering from a lack of interest due to the absence of the role of specialists, and the lack of plans to build hospitals or establish modern health centers due to the lack of financial allocations resulting from the oil crisis and the deterioration of the security and economic conditions, and this was reflected in the health of citizens and society, diseases have spread and deaths increased ${ }^{2}$.

On the energy level: As President Muhammad Buhari was unable to find effective solutions to the problem of confusion in the state's sectors, including the electricity sector, most regions of Nigeria continued to suffer from a lack of supply with sufficient energy, and from here most of the factories that produce local production were stalled. This deepened inflation, and placed Nigeria in an embarrassing position in front of its lending countries ${ }^{3}$.

On the security front, President (Muhammad Buhari) faced a deteriorating security situation, due to the continuing activities of the armed movements, foremost of which is the (Boko Haram) movement, and the phenomenon of the displacement of millions of citizens from their areas of residence continued. The president persuaded investors to implement projects in the country ${ }^{4}$.

President Muhammadu Buhari also faced another challenge that is no less dangerous than what we mentioned, namely: the drop in oil prices, as those prices fell until they reached (37.80) US dollars per barrel in $(2015)^{5}$, which increased the problems of the country, especially That wealth is the main source of its imports, which increased the

${ }^{1}$ Samson Edo and Augustine Ikelegbe :The Nigerian Economy - Reforms , Emerging Trends and Prospects -, Nigeria , Center for Population and Environmental Development, 2014,p.15.

${ }^{2}$ Ibid. p.14

${ }^{3}$ See: Freedom C. Onoha et al $\therefore$ Political, Economic and Security Challenges Facing President Buhari, Al-Jazeera, p. 5, on the website.

https://studies.aljazeera.net/ar/reports/2015/07/7

${ }^{4}$ Ibid, pp. 3-4.

${ }^{5}$ Crude Oil Price (US\$/Barrel), Production (mbd)and Export (mbd): Central Bank of Nigeria , Abuja , Nigeria , On the link:https://www. cbn.gov.ng /rates/ crude oil .asp /2020 /6/6 


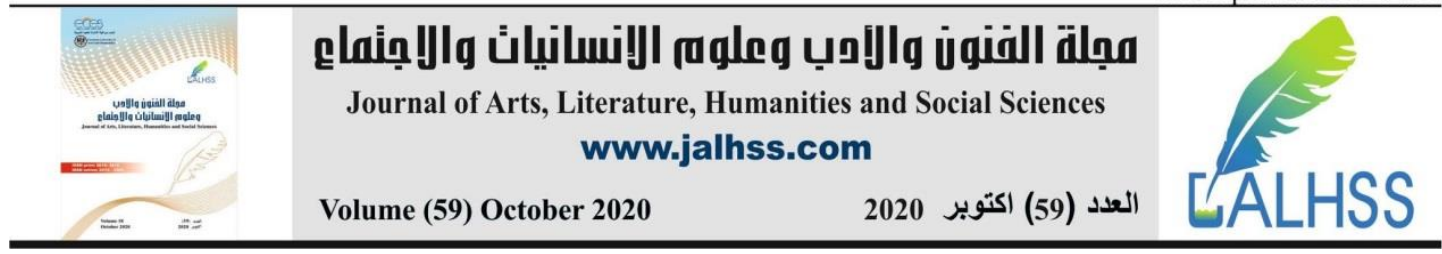

state of financial deficit and the accumulation of debts and their benefits, and the effect of this matter on the amount of government spending on the projects promised by the President, thus exacerbating the problems of poverty and unemployment ${ }^{1}$.

The crisis of low oil prices and the security chaos and economic deterioration that prevailed in the country contributed to the movement of the inhabitants of the oil-rich Niger Delta region, the movement of the citizens of the region to demand independence and economic deterioration, which led to the movement of the residents of the Niger Delta region, rich in oil wealth, to demand independence, which led to the outbreak A war between the government and the inhabitants of this region, and this war left hundreds of dead, widows and orphans, which deepened the suffering of society in Nigeria in general ${ }^{2}$.

The government's decisions against farmers and fishermen in some areas of the country, including the Niger Delta region, had a negative impact on the living conditions of the population, and to make matters worse, the government issued prison sentences and death sentences for those who violated its decisions, all of which doubled the phenomena of poverty and unemployment as well as eroding legitimacy. The government, out of frustration and popular rejection of its measures, not only succeeded in reform, but also contributed to exacerbating problems and crises ${ }^{3}$.

Among the other challenges facing President (Mohammad Buhari), is the continuous conflict between farmers and herders, and the increase in kidnappings and piracy cases, which made the Nigerian citizen live in a state of anxiety and terror that was reflected in his daily life ${ }^{4}$.

It is clear from the above that: The first term of President (Muhammad Buhari) was the best for Nigeria compared to previous governments, but it was not without challenges, including the crisis of low oil prices, the continuation of the activity of (Boko Haram) movement, corruption, unemployment, poverty and epidemics, which hindered the achievement of what Urge President (Muhammad Buhari) to implement his programs.

${ }^{1}$ Hakim Najmuddin: After Muhammad Bukhari announces his candidacy - Will the Nigerian elections 2019 witness surprises - African Readings, 2018, p. 40, available on the website. https://www.qiraatafrican.com/index.php/home/category/5?page $=10$

${ }^{2}$ Mbalisi Onyeka Festus :Energy Crisis and Its Effects on National Development - The Need For Environmental Education in Nigeria - , British Journal of Education , European Center for Research Training and Development, UK, Vol.3 , No.1 , 2015,p.29.

${ }^{3}$ Eghosa Osa Ekhator : Public Regulation of the Oil and Gas Industry in Nigeria - An Evaluation -, Journal Annual Survey of International and Comparative Law , Golden Gate University School of Law, USA, Vol.21 , No.1 , 2016, p.77.

${ }^{4}$ Agaptus Nwozor and Segun Oshewolo : Election Governance and Consolidation in Nigeria - An Assessment of The 2011 and 2015 Presidential Elections -,UNIUYO Journal of Humanities , Faculty of Arts , University of Uyo , Nigeria , Vol.21 , No.2 ,2017, p.400. 


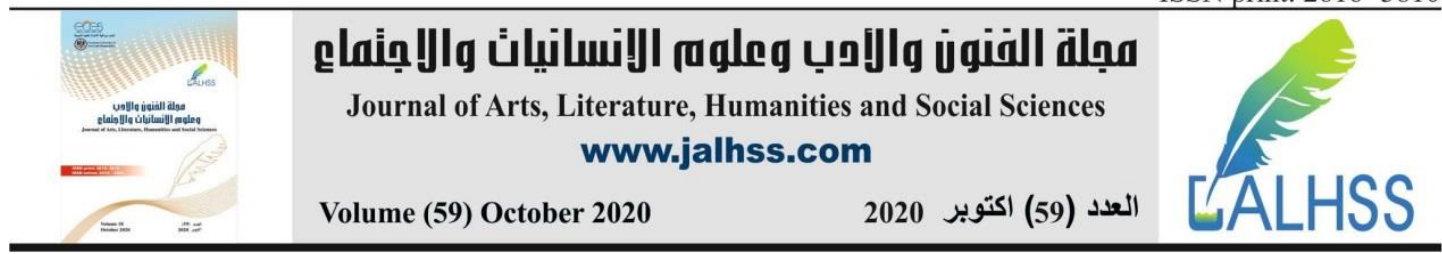

\section{Conclusion :}

In brief Nigeria suffers from many security, economic, social and political challenges, despite the achievements and reforms that successive presidents have sought to implement.The President (Goodluck Jonathan) in the year (2010-2015) was crowned with achievements according to what he stated in his electoral program. Many challenges made his projects and plans falter and failed to achieve this endeavor, especially after he assumed the presidency in (2010) to fill the gap that occurred after the death of the president (Omar Musa Yar'Adua) and as his deputy, and in the elections of (2011) Goodluck Jonathan nominated himself for the presidency, This nomination was the beginning of an era of problems that faced this president because he belonged to the Christian region and that the term of the late former president (Omar Musa Yarada) did not end yet, so this problem posed a challenge to him by the Muslim region, despite all the efforts he made to address the challenges that he I faced him, and he could not succeed in the economic and administrative reforms that he presented, including the economic and administrative challenges, and challenges continued during the term of President (Goodluck Jonathan), including tribal, regional and ethnic conflict, financial and administrative corruption, and the term of his rule was distinguished by Bazdia Widespread bribery, crime and violence.

After the collapse of the (Goodluck Jonathan) government, the country entered into a political crisis that almost threatened national security in Nigeria. However, political awareness among some parties made them put an end to this collapse after the coming of Muhammad Buhari to power through elections, Despite the fraud and doubts similar to these elections, (Muhammad Buhari) was able to lead the country at this stage with his electoral program, which was also subjected to many setbacks and challenges that made him not achieve what he aspired to, so these crises and challenges remained, one of which is a crisis of decline. Oil prices, tribal, ethnic and regional conflicts, conflict between farmers and herders, and epidemics. In conclusion, the civil rule that Nigeria knew after 1999 did not achieve the prosperity and development that the people aspired to do. On the contrary, the matter worsened as a result of partisan interests and terrorist movements represented by the (Boko Haram) movement, which constituted an obstacle to achieving progress, and as a result this matter led the country to a phenomenon Political instability.

\section{Reference}

1.Report of the Commonwealth Observer Group , Nigeria Presidential and National Assembly Elections 28 March 2015, UK, 2015.

2. Jideofor Adibe: The 2015 Presidential Elections in Nigeria - The Issues and Challenges -, Journal of African Foreign Affair, The Brookings Institution, USA, Vol.2, No.1, 2015.

3.Looking at Amir Saeed: Nigeria - The Map and the Compass - Afrikaans Reading Magazine, Islamic Forum, London, Issue 5, 2010.

4. Lauren Ploch: Report on Nigeria's 2015 General Elections 28 March and 11 April 2015, The Nigeria Civil Society Situation Room, Policy and Legal Advocacy Center, Nigeria, 2015. 


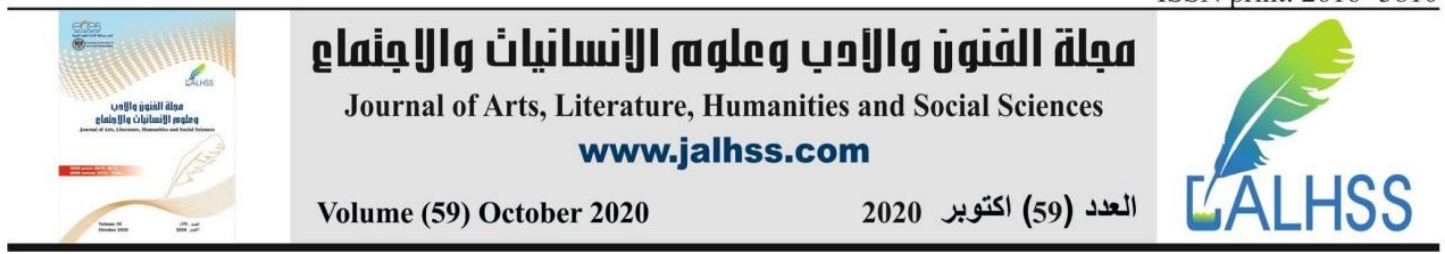

5. General Elections in Nigeria 2011, Al Jazeera, on the website: https://www.aljazeera.net/encyclopedia/events/2011/8/11/

6.Falade : Political Participation in Nigerian Democracy - A Study of Some Selected Local Government Areas in Ondo State , Nigeria -, Global Journal of Human - Social Science, Global Journals Inc., USA, Vol.14 , No.8, 2014.

7. Muddassir Ahmad Gado and Sanusi Abdulwasiu : Challenges Militating against Reform Policy, Economic Growth and Development in Nigeria - Reflections on The Transformation Agenda of Good luck Jonathan's Administration-,Saudi Journal of Humanities and Social Sciences , Scholars Middle East Publishers , United Arab Emirates, Vol.2, No.8, 2017.

8. Oladayo Nathaniel Awojobi : Cultivating Policy for Development in Nigeria - An Appraisal of President Good luck Jonathan's Transformation Agenda (2011-2014),International Research Journal of Humanities ,Engineering and Pharmaceutical Sciences , Association for Innovation, India, Vol.1,No.9,2015.

9. Blessing Thom Otuya : President Goodluk Jonathan's Transformation Agenda and Nigeria's Foreign Policy, Journal Social Science Review, a not-for-pro it organization, USA, Vol.1, No.1, 2015.

10. Daniel Egiegba Agiboa : The Evolution of Democratic Politics and Current Security Challenges in Nigeria - Retrospect and Prospecy -, Journal Democracy and Security, Taylor and Francis , 2013.

11. Love Arugu and Comrade John Kalama Mnim : Leadership and The Challenges in Nigeria - An Assessment of President Good luck Ebele Jonathan Administrative Style -, International Journal in Advanced Research in Social Engineering and Development Strategies, Science Publishing Corporation, United Arab Emirates , Vol.2, No.1, 2014.

12. Kia Bariledum and Others : Foreign Democratic Assistance To Nigeria (19992015) - The Nexus Between Strategy and Election Result -, Global Journal of Political Science and Administration, European Center for Research Training and Development , UK, Vol.4 , No.4 , 2016.

13. Alexander Omotayo Bandipo : The role of The New Media in The Electioneering Process of Developing Nations - A Case Study of Nigeria 2015 - , Master Thesis (Not Published), Faculty of Arts , University of Malta, Malta, 2016.

14. Remi Chukwudi Okeke : The Jonathan administration in Nigeria - A Postmortem Study and lessons for dictators in Africa -, World Scientific News , Darwin , Poland, Vol.70, No.2, 2017.

15. Sami El-Sayed Ahmed: Political Issues in Africa - The Second African Strategic Report (2014-2015) -, Center for African Research and Studies, International Africa University, Cairo, 2016.

16. Okechukwu Eme and Tony Onyishi: The Presidency and Cost of Governance in Nigeria - A Case of Jonathan's Administration -, Arabian Journal of Business and Management Review, American University of Kuwait and Zainab Arabian Research Society for Multidisciplinary issues, United Arab Emirate, Vol. 3 , No. 2, 2013. 


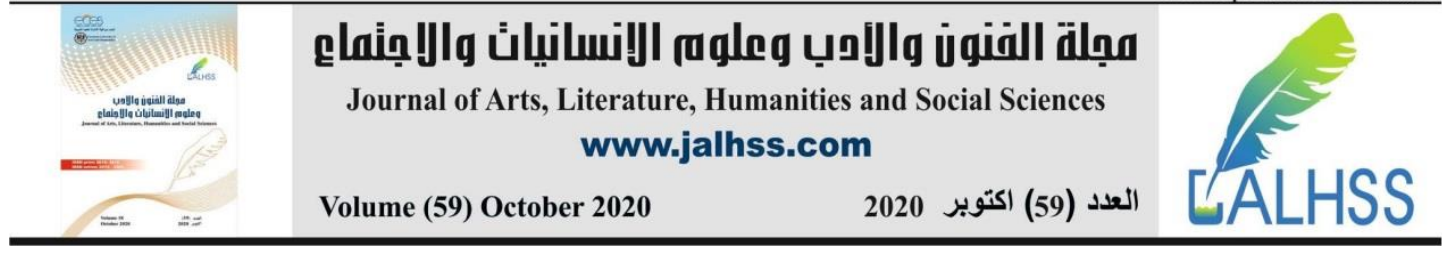

17.European Union Election Observation Mission, Final Report on the National Assembly, Presidential, Gubernatorial and State Houses of Assembly Elections, Nigeria, 2003.

18.Alexander Thurston : Background to Nigeria's 2015 Elections, USA, the CSIS Africa Program, 2015.

19. Mojeed Adekunle Animashaun : Nigeria 2015 Presidential Election - The Votes, The Fears and The Regime Change, Journal of African Elections , Electoral Institute for Sustainable Democracy in Africa, South Africa, Vol.14, No.2, 2015.

20. Ladi Hamalai , Samuel Egwu and Shola Omotola : Nigeria's 2015 General Elections - Continuity and Change in Electoral Democracy -, Library of Congress , USA, 2017.

21.European Union Election Observation Mission, Final Report Federal Republic of Nigeria , 2015.

22.Hakim Najmuddin: The Nigerian Presidential Elections - Observation and History -, Qiraat Afriqiyah Magazine, The Islamic Forum, London, Issue 25,2015.

23.Hakim Najmuddin: The Nigerian Presidential Elections - Monitoring and History , a previously mentioned source.

24. Kuwait Transparency Society: Corruption Perceptions Index 2016, Transparency International, 2017.

25. European Union Election Observation Mission , Final Report Federal Republic of Nigeria , 2015.

26. Abdulhamid Ozohu Suleiman :Democracy, good governance and development in Nigeria, Journal of Public Administration and Policy Research , University of Abuja , Nigeria, Vol.8, No.7, 2016.

27. Macaulay Akpan and Michael Eyo : Anti - Corruption War Under President Muhammadu Buhari in Nigeria - The Arsenal ,Casualties, Victories and Corruption Perception Appraisal -, Global Journal of Politics and Law Research , European Center for Research Training and Development , UK, Vol.6, No.3, 2018.

28. Freedom Onoha and Samuel Oywole: Boko Haram - The dynamics of the rise and fall of a violent group in Nigeria - Al-Jazeera, p. 5, available on the website.

https://studies.aljazeera.net/en/reports/2018/4/25

29. Taiwo J.N and Agwu M.E : Problems and Prospects of Poverty Alleviation Programmes in Nigeria , International Journal of Business and Management Review , European Center for Research Training and Development, UK, Vol.4,No.6, 2016.

30.John Paden : Muhammadu Buhari - The Challenges of Leadership in Nigeria -, Journal of International and Global Studies , Center for African and Asian Studies, Nigeria, 2016, Vol.10, No.1.

31.Idayat Hassan : Matching Campaign Promises, Public Expectations and Government Actions in The First Year of President Muhammadu Buhar's Government , Nigeria ,Center for Democracy and Development , 2016.

32.Mohammed Yamma Abdullahi and Yahuza Lzom Danjuma : Assessment of Value Based Leadership Style of President Muhammadu Buhari (2015-2018) , Research Journal of Humanities, Legal Studies and International Development, Center for Promoting Ideas , USA, Vol.3, No.1, 2019. 


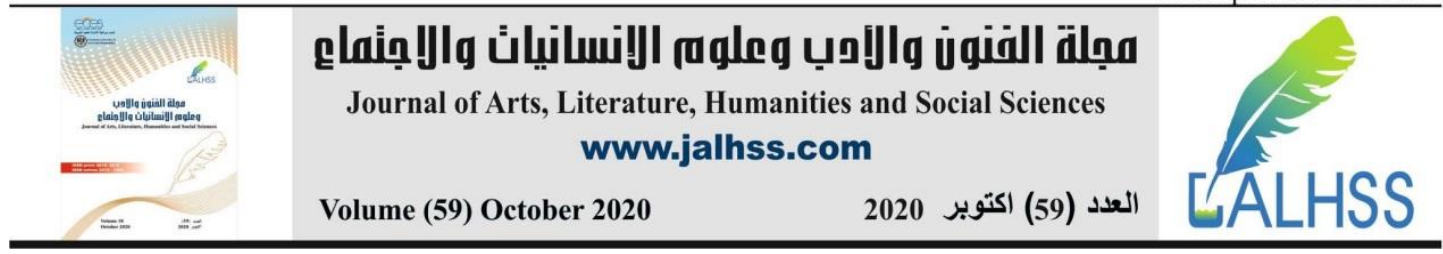

33.Erepamo Osaisai : Country Nuclear Power Profiles 2018 Edition , The Federal Republic of Nigeria , Austria, International Atomic Energy Agency ,2018.

34.Joy Uyo Ata - Agboni and Beluchi Nwanisobi : Economic Recovery Programmes of Buharl's Administration As Developmental Stage Paradigm ,International Journal of Public Administration and Management Research ,Research Center for Management and Social Studies , India , Vol. 5, No.1 , 2019.

35. Musa Hyelladzira Wakawa: Causes of Nigeria's Recession - Uneclpsing The Blame on The Previons Administration -, SSRN Papers, 24 Apr 2018. On The link: https://ssrn.com/abstract $=3157154$

36. Pallavi Roy : Ant - Corrupton in Nigeria - A political setlements analysis - , UK, University of London , 2017.

37. Dickson Monday and Ezirim Gerald : The Political Economy of Recession in Nigeria's Fourth Republic , African Journal of Political Science and International Relations, Academic Journals, Vol.11, No.7 , 2017.

38. IIesanmi Akanmidu Paul : A Historical Perspective of Petroleum on Nigeria's Economic Crisis Since Independence, Global Journal of Human - Social Science, Global Journals Inc., USA, Vol.15, No.2, 2015.

39. Lucky Ujuju and Godday Oboro: The Nigeria Debt Structure and its Effects on Economic, International Journal of Business and Management Review, European Center for Research Training and Development, UK, Vol.5, No. 10, 2017.

40. Adams Oluwadamilola Kemi: Nigeria's Economy Challenges - Causes and Way Forward -, Journal of Economics and Finance, International Organization of Scientific Research, India, Vol.10, No.2, 2019.

41. Lauren Ploch Blanchard and Tomas Husted : Nigeria - Current Issues and U.S. Policy -, USA, Congressional Research Service, 2019.

42. Robert Dode : The Political Economy of Resource Curse and the Niger Delta Crisis in Nigeria - Matters Arising -, European Journal of Sustainable Development , Science and Public Administration University of UYO , Nigeria , Vol.1 , No.2 2012.

43. Cordelia Onyinyechi Omodero and Ogechi Eberechi Alpheaus : The Effect of Foreign Debt on the Economic Growth of Nigeria, Management Dynamics in the Knowledge Economy , Faculty of Management Studies - University of Delhi , India , Vol.7, No.3, 2019.

44. Department of Economic and Social Affairs: Handbook of World Statistics, Statistics Division Journal, New York, Issue 42, 2018.

45.Zhenbo Hou and Others : The Oil Price Shock of 2014 , London , Overseas Development Institute, 2014.

46. Freedom C. Onoha et al $\therefore$ Political, Economic and Security Challenges Facing President Buhari, Al-Jazeera, on the website.

https://studies.aljazeera.net/ar/reports/2015/07/7

47. Hakim Najmuddin: After Muhammad Bukhari announces his candidacy - Will the Nigerian elections 2019 witness surprises - African Readings, 2018, available on the website.

https://www.qiraatafrican.com/index.php/home/category/5?page $=10$ 


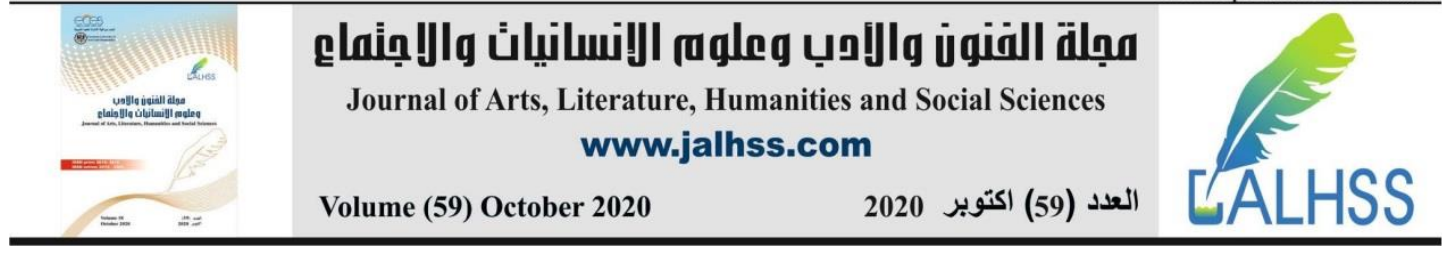

48. Mbalisi Onyeka Festus :Energy Crisis and Its Effects on National Development The Need For Environmental Education in Nigeria - , British Journal of Education , European Center for Research Training and Development, UK, Vol.3 , No.1 , 2015. 49. Eghosa Osa Ekhator : Public Regulation of the Oil and Gas Industry in Nigeria An Evaluation -, Journal Annual Survey of International and Comparative Law , Golden Gate University School of Law, USA, Vol.21, No.1 , 2016.

50. Agaptus Nwozor and Segun Oshewolo : Election Governance and Consolidation in Nigeria - An Assessment of The 2011 and 2015 Presidential Elections -,UNIUYO Journal of Humanities , Faculty of Arts , University of Uyo , Nigeria , Vol.21 , No.2 ,2017.

51. Atanda Abdulwaheed Isiaq, Oluwashina Moruf Adebiyi and Adebola Rafiu Bakare: Ethnicity and Election Outcomes in Nigeria - Interrogating the 2015 Presidential Election -, Journal of African Elections, Electoral Institute for Sustainable Democracy in Africa, Southern Africa, Vol.17, No. 1, 2018.

52. Lansana Gberie: The 2011 Elections in Nigeria - a new dawn -, South Africa, Institute for Security Studies, 2011.

53. Lauren Ploch: Report on Nigeria's 2015 General Elections 28 March and 11 April 2015, The Nigeria Civil Society Situation Room, Policy and Legal Advocacy Center, Nigeria, 2015.

54. Lauren Ploch: Nigeria - Elections and Issues for Congress -, Nigeria, Congressional Research Service, 2011.

55. Nkwachukwu Orji: The 2015 Nigerian General Elections, Journal Africa Spectrum, German Institute of Global and Area Studies, Germany, Vol.50, No. 2, 2015.

56. Nigeria House of Representatives, Inter-Parliamentary Union, 2015, On the link: http://archive.ipu.org/parline-e/reports/2363_E.htm

57. Transparency International: Corruption Perceptions Index 2018, Germany, 2019.

58. Transparency International: Corruption perceptions index, Germany, 2011, 2012, 2013, 2014, 2015, 2017.

59.Esekumemu Victor Clark : The Politics of Oil in Nigeria - Transparency and Accountability for Sustainable Development in the Niger Delta -, American International Journal of Contemporary Research , Center for Promoting Ideas , USA , Vol.6, No.4 , 2016 .

60. Samson Edo and Augustine Ikelegbe :The Nigerian Economy - Reforms , Emerging Trends and Prospects -, Nigeria , Center for Population and Environmental Development, 2014.

61. Crude Oil Price (US\$/Barrel), Production (mbd)and Export (mbd): Central Bank of Nigeria , Abuja , Nigeria , On the link:https://www. cbn.gov.ng/rates/ crude oil .asp /2020/6/6 